\title{
Ground Motion Estimation using Site Response Analysis for Deep Sedimentary Deposits
}

\author{
Md. Zillur Rahman", 2 \\ Sumi Siddiqua ${ }^{2}$ \\ A. S. M. Maksud Kamal ${ }^{3}$ \\ Mir Fazlul Karim ${ }^{4}$ \\ Nazrul I. Khandaker ${ }^{5}$
}

Department of Geology, University of Dhaka, Bangladesh, e-mail: zillur@ du.ac.bd

${ }^{2}$ School of Engineering, University of British Columbia, Okanagan Campus, Kelowna, Canada

${ }^{3}$ Department of Disaster Science and Management, University of Dhaka, Bangladesh

${ }^{4}$ Geocomp Corporation, Massachusetts, USA

${ }^{5}$ School of Arts and Sciences: Dept. of Earth and Physical Sciences, York College (The City University of New York), USA 


\section{Introduction}

This study involves Ground Motion Estimation using Site Response Analysis for Deep Sedimentary Deposits of Dhaka City located in the central part of the Bengal basin which is one of the oldest urban seat of the Indian subcontinent.

In last three decades the city of Dhaka has become one of the 20 mega cities of the world having population of $20,000,000$ by ranking this to be the $10^{\text {th }}$ mega-city in the world.

Many geologists and seismologists consider Dhaka as one of the riskiest cities in the world due to many uncontrolled construction practices, poorly understood or inadequately studied seismo-tectonic boundary conditions over deep sedimentary deposits of the Bengal basin.

A Nonlinear Seismic Site Response Analysis is performed where the components of seismic hazard analysis are shown in the figure.

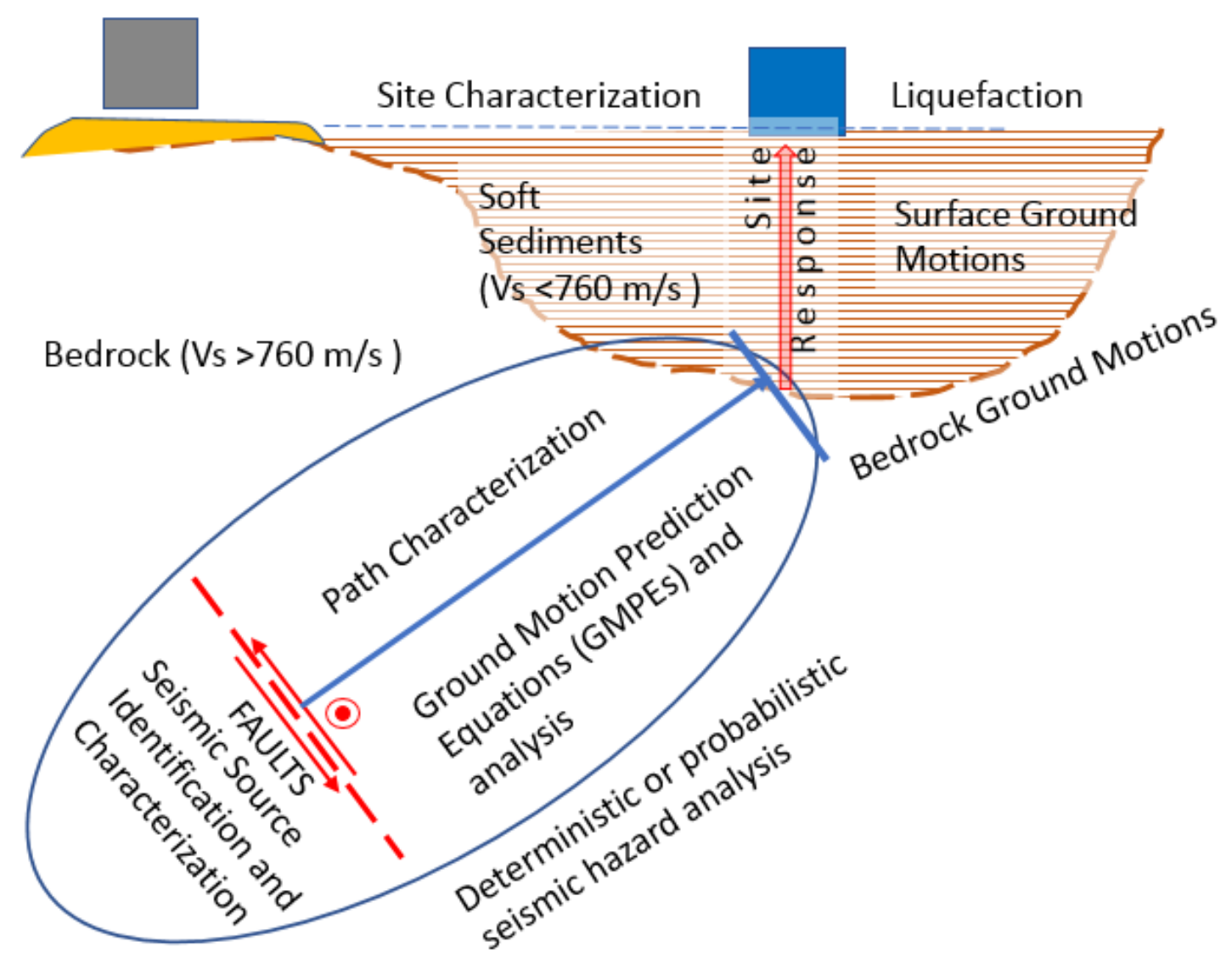

Fig. 1. Components of seismic hazard analysis 


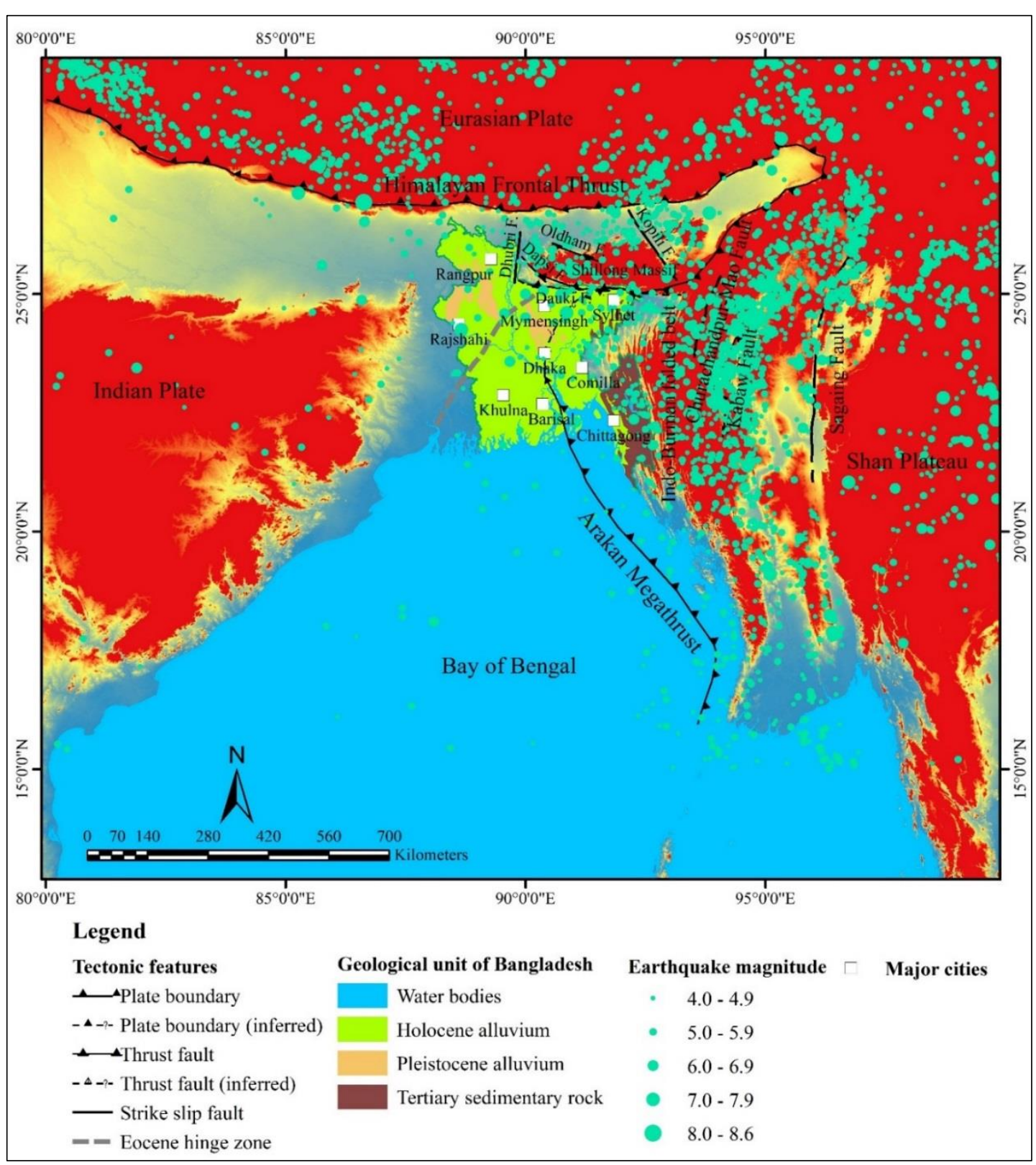

Fig. 1. Seismotectonic map of Bangladesh and surrounding regions (modified from Rahman et al. 2018).

\section{Tectonics and seismic source:}

The records of historical earthquakes indicate that three large magnitude earthquakes occurred during the last 150 years within and in close proximity to Bangladesh.

Magnitudes of these earthquakes ranged from 6.9 to 8.7 occurring between 1885 and 1918 .

It is believed that the 6.9 magnitude Bengal earthquake occurred at about $50 \mathrm{~km}$ from the city'

Many consider that the epicenter of this earthquake was $170 \mathrm{~km}$ away from Dhaka city and others inferred the epicenter to be somewhere along Madhupur fault, approximately $50 \mathrm{~km}$ away.

Bedrock ground motion parameters estimated using probabilistic seismic hazard analysis have been used for site response analysis. 


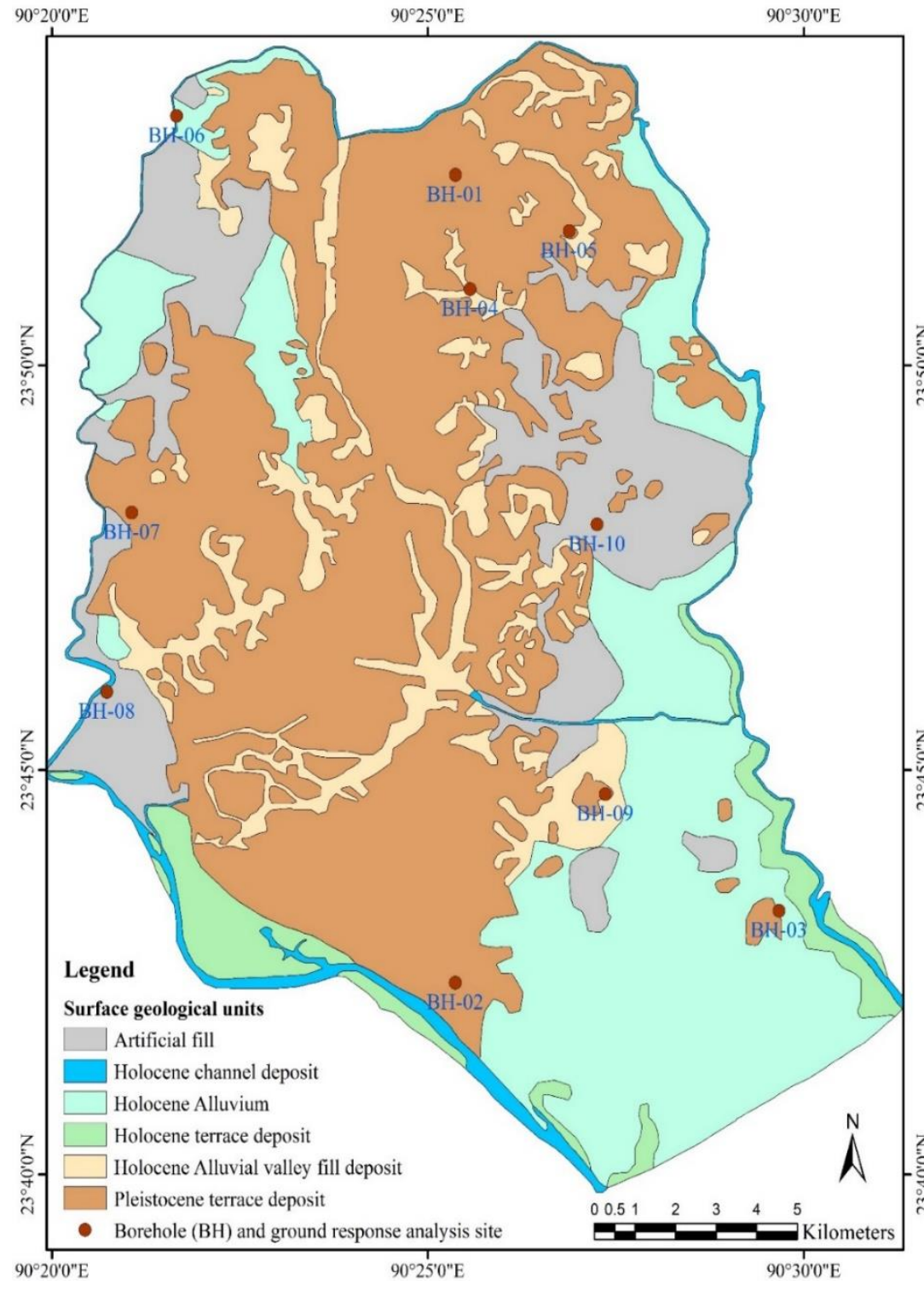

\section{Generalized geology of Dhaka city :}

The Mega City of Dhaka occupies an unique geological location and was built on a PlioPleistocene terrace in the central part of the Bengal basin. The subsurface geology is firm and almost homogenously consistent. There are three distinct geomorphological units which are raised considerably about $6 \mathrm{~m}$ AMSL. The surrounding floodplains are at about 4m AMSL. The ground is composed of Madhupur Clay. The Clay is Over-consolidated. The shear strength properties are considerably high. The Thickness of Madhupur Clay is about $6 \mathrm{~m}$ and it overlies a

Fig. 2. Surface geological map of Dhaka City (modified from Rahman et al. 2015) showing geotechnical borehole locations and ground response analysis sites. firm sandstone bed, geologically known as Dupi Tila. 


\section{Generalized Geotechnical and seismic properties of Dhaka ground}

(After Karim, M F and Rahman, M Z, 2002)

\begin{tabular}{l|l|l|l|l|l|l|l} 
Formation & $\begin{array}{l}\text { Average } \\
\text { Thickness, } \\
\text { meter }\end{array}$ & $\begin{array}{l}\text { Consistency } \\
\text { and } \\
\text { Material }\end{array}$ & $\begin{array}{l}\text { Average } \\
\text { Moisture } \\
\text { content, } \\
\mathbf{w}_{\mathrm{n}} \%\end{array}$ & $\begin{array}{l}\text { Dry unit } \\
\text { Weight, } \\
\gamma_{\mathrm{d}} \\
\mathrm{kN} / \mathrm{m}^{3}\end{array}$ & $\begin{array}{l}\text { Average } \\
\text { Undrained } \\
\text { Shear } \\
\text { Strength, } \\
\mathrm{s}_{\mathrm{u}} \mathrm{kPa}\end{array}$ & $\begin{array}{l}\text { N value } \\
\text { Range } \\
\text { (SPT } \\
\text { count) }\end{array}$ & $\begin{array}{l}\text { Shear Wave } \\
\text { Velocity, } \mathrm{m} / \mathrm{sec}\end{array}$ \\
\hline $\begin{array}{l}\text { Madhupur } \\
\text { Clay }\end{array}$ & 6 & $\begin{array}{l}\text { Stiff } \\
\text { Clay-SILT }\end{array}$ & 25 & 16 & 150 & $10-30$ & $>200<300$ \\
\hline $\begin{array}{l}\text { Dupi Tila } \\
\text { Sandstone }\end{array}$ & $>90$ & $\begin{array}{l}\text { Soft } \\
\text { Sedimentar } \\
\text { y rock } \\
\text { (Sandstone } \\
\text { with } \\
\text { occasional } \\
\text { Claystone) }\end{array}$ & $<20$ & $>16$ & $\phi>30^{\circ}$ & $\begin{array}{l}\text { Often } \\
\text { Refusal }\end{array}$ & $>350<450$ \\
\end{tabular}




\section{Seismic Site Response Analysis}

Surface ground motion of soft sedimentary deposit is generally estimated by multiplying the bedrock motion with the site amplification factor that is estimated from the average shear wave velocity of the top $30 \mathrm{~m}\left(\mathrm{~V}_{\mathrm{s}}{ }^{30}\right)$ based on the site classes of National Earthquake Hazards Reduction Program (NEHRP) site, USA.

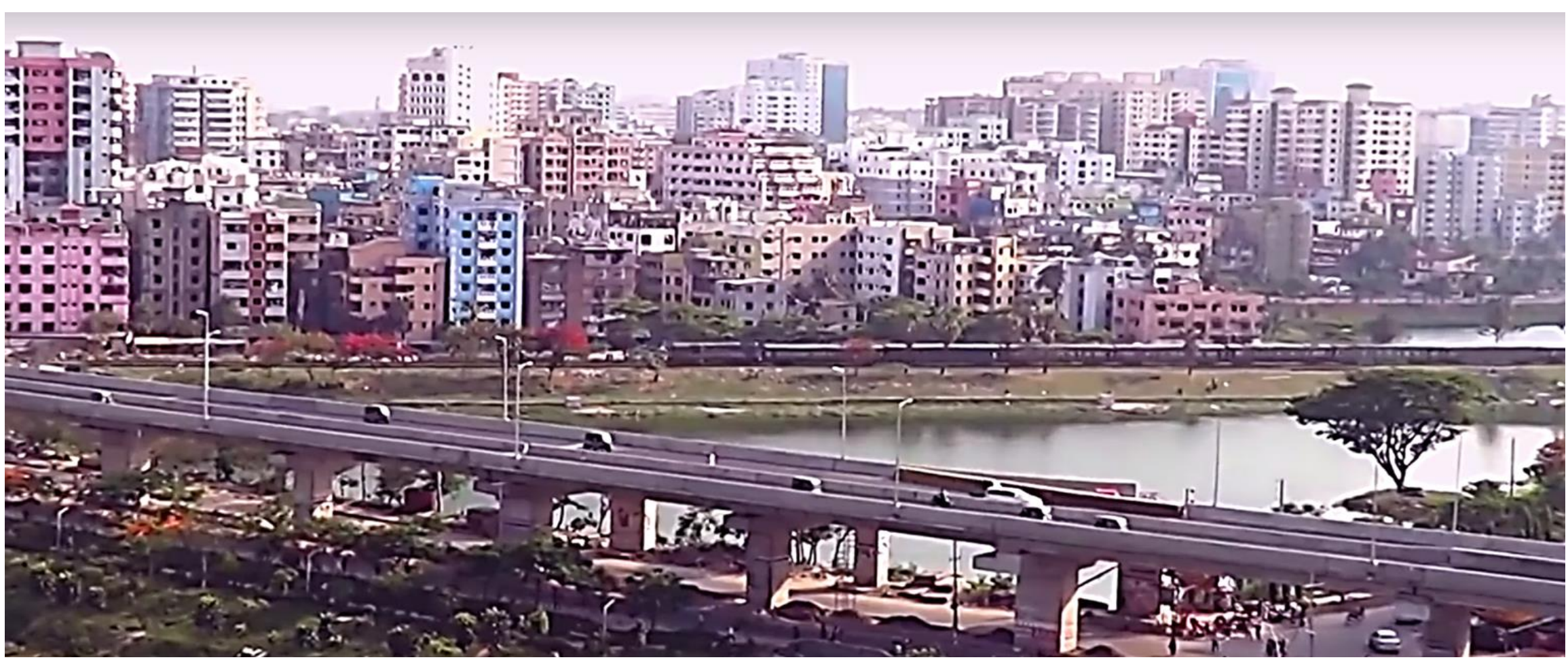




\section{NEHRP (National Earthquake Hazards Reduction Program), USA}

\begin{tabular}{|c|c|c|}
\hline \multicolumn{3}{|c|}{ NEHRP, USA } \\
\hline $\begin{array}{l}\text { Site class or } \\
\text { Soil profile } \\
\text { type }\end{array}$ & Description & $\begin{array}{l}\text { Average shear } \\
\text { wave velocity of } \\
\text { top } 30 \mathrm{~m}(\mathrm{~m} / \mathrm{sec})\end{array}$ \\
\hline A & Hard rock & $>1500$ \\
\hline B & Rock & $760-1500$ \\
\hline $\mathrm{C}$ & $\begin{array}{l}\text { Very dense } \\
\text { soil/soft rock }\end{array}$ & $360-760$ \\
\hline D & Stiff soil & $180-360$ \\
\hline E & Soft soil & $<180$ \\
\hline $\mathbf{F}$ & \multicolumn{2}{|c|}{$\begin{array}{l}\text { Special soils requiring site- } \\
\text { specific evaluation (1. Soils } \\
\text { vulnerable to potential failure or } \\
\text { collapse under seismic loading, } \\
\text { e.g., liquefiable soils, quick and } \\
\text { highly sensitive clays, collapsible } \\
\text { weakly cemented soils; } 2 \text {. Peats } \\
\text { and/or highly organic clays ( } 3 \mathrm{~m} \\
\text { or thicker layer); } 3 \text {. Very highly } \\
\text { plasticity clays ( } 8 \mathrm{~m} \text { or thicker } \\
\text { layer with plasticity index }>75 \text { ); } \\
4 \text {. Very thick soft/medium stiff } \\
\text { clays ( } 36 \mathrm{~m} \text { or thicker layer)) }\end{array}$} \\
\hline
\end{tabular}

For example : Short period ground motion, $S_{\mathrm{s}}(0.2 \mathrm{~s})=0.3 \mathrm{~g}$

Long period ground motion, $S_{1}(1.0 \mathrm{~s})=0.13 \mathrm{~g}$ at $\mathrm{Vs}^{30}=760 \mathrm{~m} / \mathrm{s}$

Table 1, 2 and 3: Site Classes and Site Coefficients (BSSC, 2015)

\begin{tabular}{|c|c|c|c|c|c|c|}
\hline $\begin{array}{ll} & \text { Site } \\
& \text { Class } \\
\end{array}$ & $\begin{array}{ll} & \mathrm{S}_{\mathrm{s}} \leq \\
\end{array}$ & $\mathrm{S}_{\mathrm{S}}=0.5$ & $\begin{array}{ll} & \mathrm{SS}_{\mathrm{S}}= \\
\end{array}$ & $\mathrm{S}_{\mathrm{S}}=1.0$ & $\begin{array}{ll} & \mathrm{S}_{\mathrm{S}}= \\
\end{array}$ & $\mathrm{S}_{\mathrm{S}} \geq 1.5$ \\
\hline A & 0.8 & 0.8 & 0.8 & 0.8 & 0.8 & 0.8 \\
\hline B & 0.9 & 0.9 & 0.9 & 0.9 & 0.9 & 0.9 \\
\hline C & 1.3 & 1.3 & 1.2 & 1.2 & 1.2 & 1.2 \\
\hline D & 1.6 & 1.4 & 1.2 & 1.1 & 1.0 & 1.0 \\
\hline$E$ & 2.4 & 1.7 & 1.3 & See Section 11.4.7 & See Section 11.4.7 & See Section 11.4.7 \\
\hline $\mathrm{F}$ & See Section 11.4.7 & See Section 11.4.7 & See Section 11.4.7 & See Section 11.4.7 & See Section 11.4.7 & See Section 11.4.7 \\
\hline
\end{tabular}

\begin{tabular}{|c|c|c|c|c|c|c|}
\hline ite Class & $S_{I} \leq 0.1$ & $S_{1}=0.2$ & $S_{t}=0.3$ & $S_{I}=0.4$ & $S_{I}=0.5$ & $s_{1} \geq 0.6$ \\
\hline A & 0.8 & 0.8 & 0.8 & 0.8 & 0.8 & 0.8 \\
\hline B & 0.8 & 0.8 & 0.8 & 0.8 & 0.8 & 0.8 \\
\hline C & 1.5 & 1.5 & 1.5 & 1.5 & 1.5 & 1.4 \\
\hline $\mathrm{D}$ & 2.4 & $2.2^{1}$ & $2.0^{1}$ & $1.9^{1}$ & $1.8^{1}$ & $1.7^{1}$ \\
\hline $\mathrm{E}$ & 4.2 & $3.3^{1}$ & $2.8^{1}$ & $2.4^{1}$ & $2.2^{1}$ & $2.0^{1}$ \\
\hline F & See Section 11.4.7 & See Section 11.4.7 & See Section 11.4.7 & See Section 11.4.7 & See Section 11.4.7 & See Section 11.4.7 \\
\hline
\end{tabular}




\section{NEHRP (National Earthquake Hazards Reduction Program), USA}

- NEHRP amplification factor does not consider the response of the soft deposits that exist below $30 \mathrm{~m}$ depth.

- In the study area (Dhaka City, Bangladesh), the depth of the soft sedimentary deposits above the bedrock formation $\left(\mathrm{V}_{\mathrm{s}}{ }^{30} \geq 760 \mathrm{~m} / \mathrm{s}\right)$ is more than $200 \mathrm{~m}$.

- The soft sedimentary deposits are composed of sand, silt, and clay of the Holocene to Pliocene age.

- The state of seismic boundary between the soft sedimentary deposits and bedrock is not of a geological type but rather a gradational type.

- The impedance contrast is not very high along this boundary and the sediments above and below the boundary are not consolidated.

- Therefore, the ground motion estimation using empirically estimated amplification factor is not appropriate for the depth of soft deposits greater than $30 \mathrm{~m}$. 


\section{One-dimensional Site Response Analysis}

- One-dimensional site response analysis can be used for deep sedimentary deposits.

- The properties of the soft deposits are not linear.

- The ground motion estimation using one-dimensional linear and equivalent-linear response analyses become inaccurate at high strain (Kaklamanos et al., 2015).

- The nonlinear site response analysis has been performed to estimate the ground motion of deep and soft sedimentary deposits using DEEPSOIL (Hashash et al., 2017). 


\section{One-dimensional Site Response Analysis}

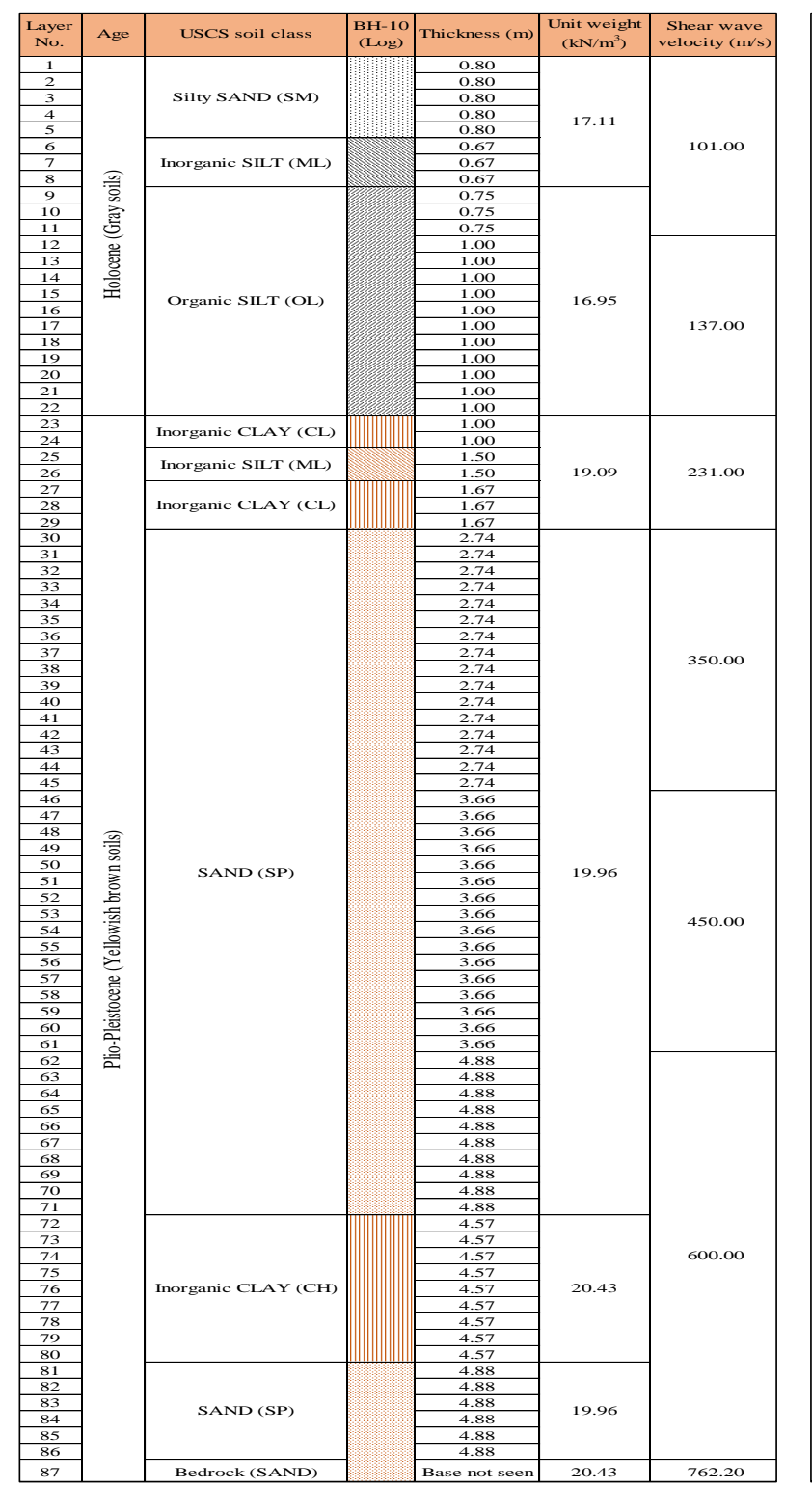

Fig. 3. soil profile (300 m depth)

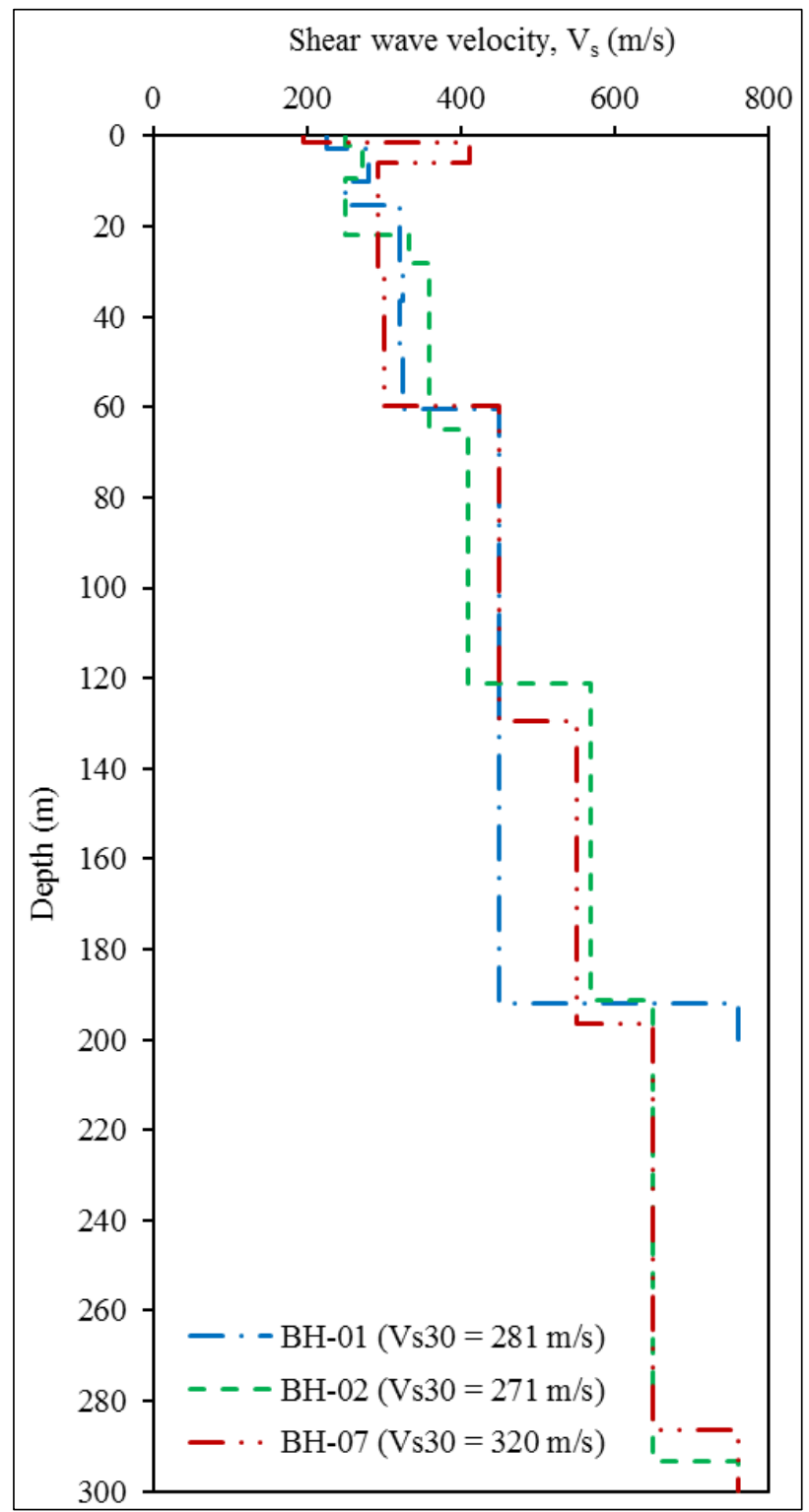

Fig. 4. shear wave velocity profile
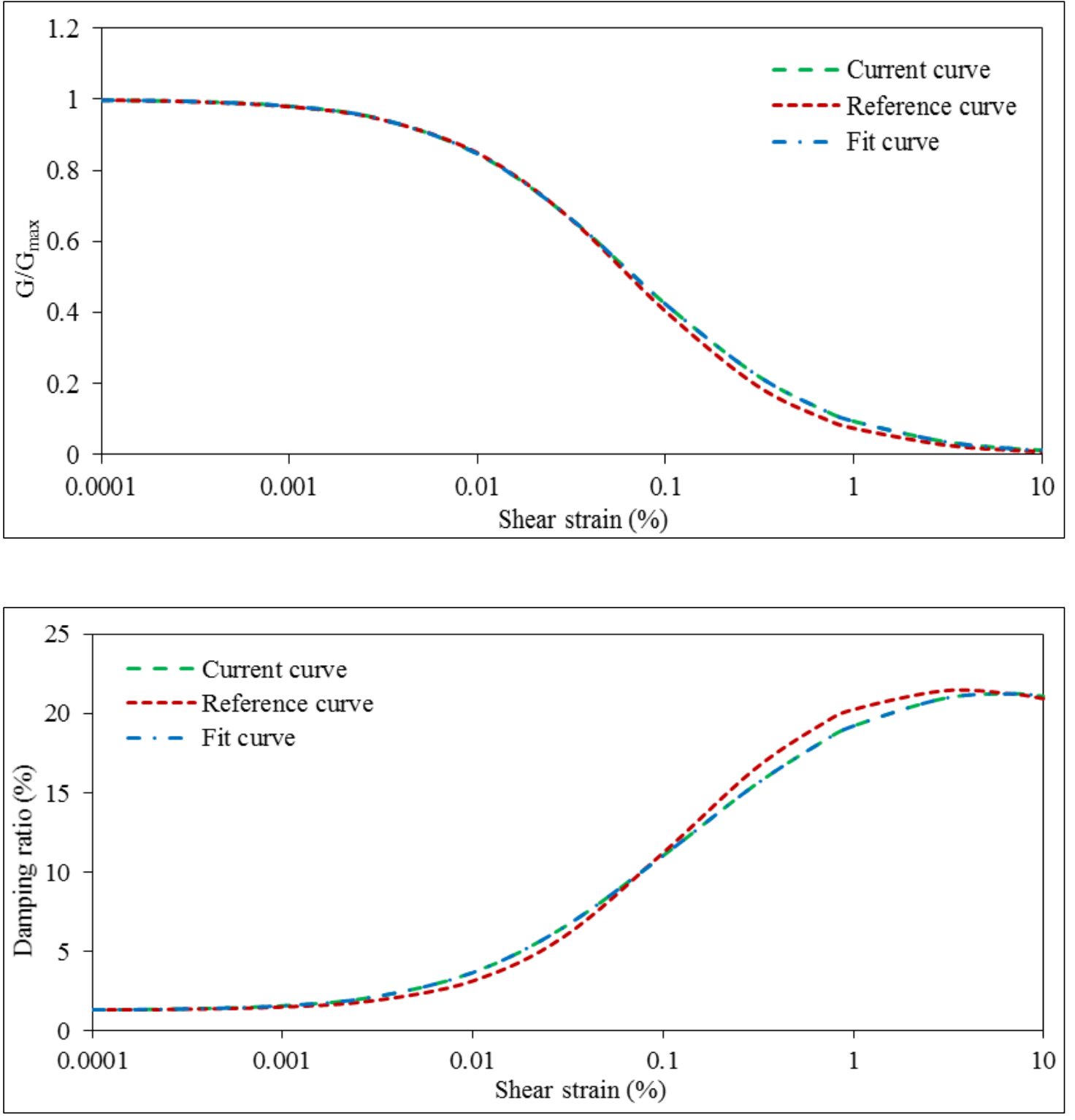

Fig. 5. Modulus reduction and damping curves 


\section{Nonlinear Site Response Analysis}

Dhaka City Uniform Hazard Spectra

Spectral Response @ 5\% Damping - Average Horizontal Component

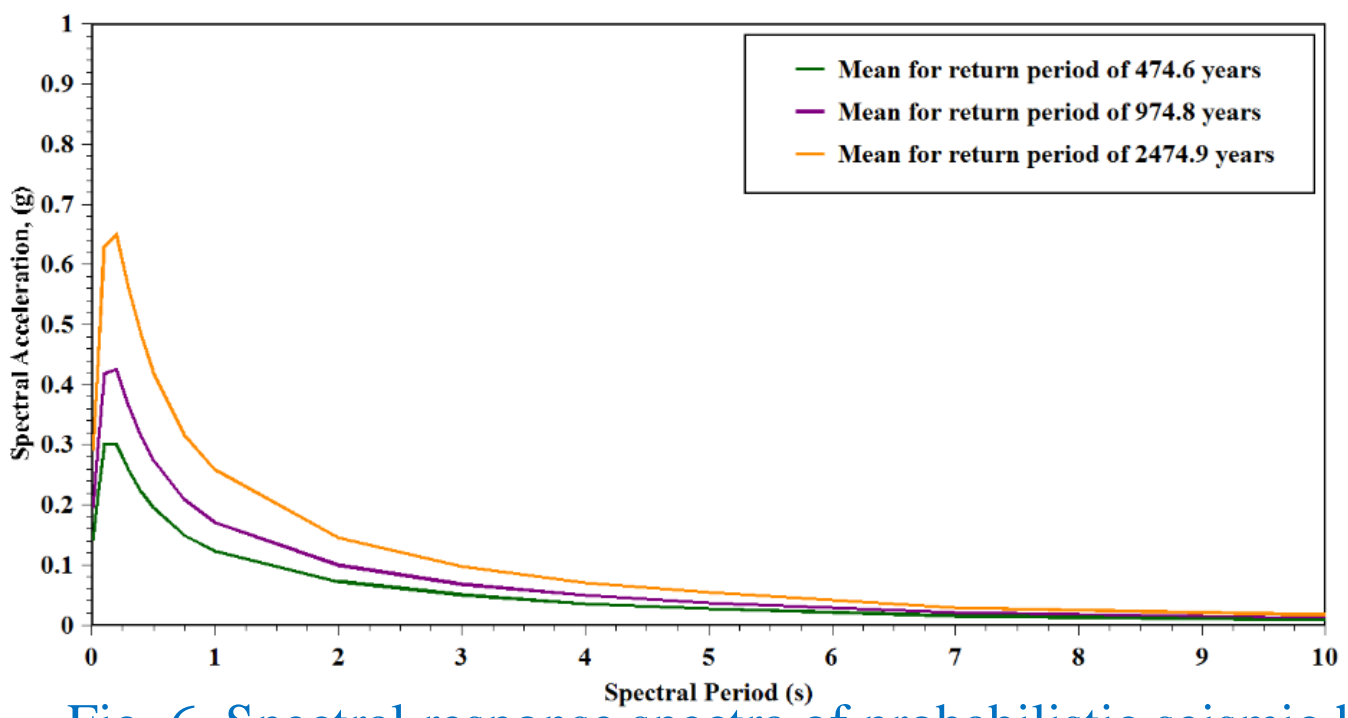

Fig. 6. Spectral response spectra of probabilistic seismic hazard analysis using EZ-FRISK (Fugro Consultants Inc., 2014)

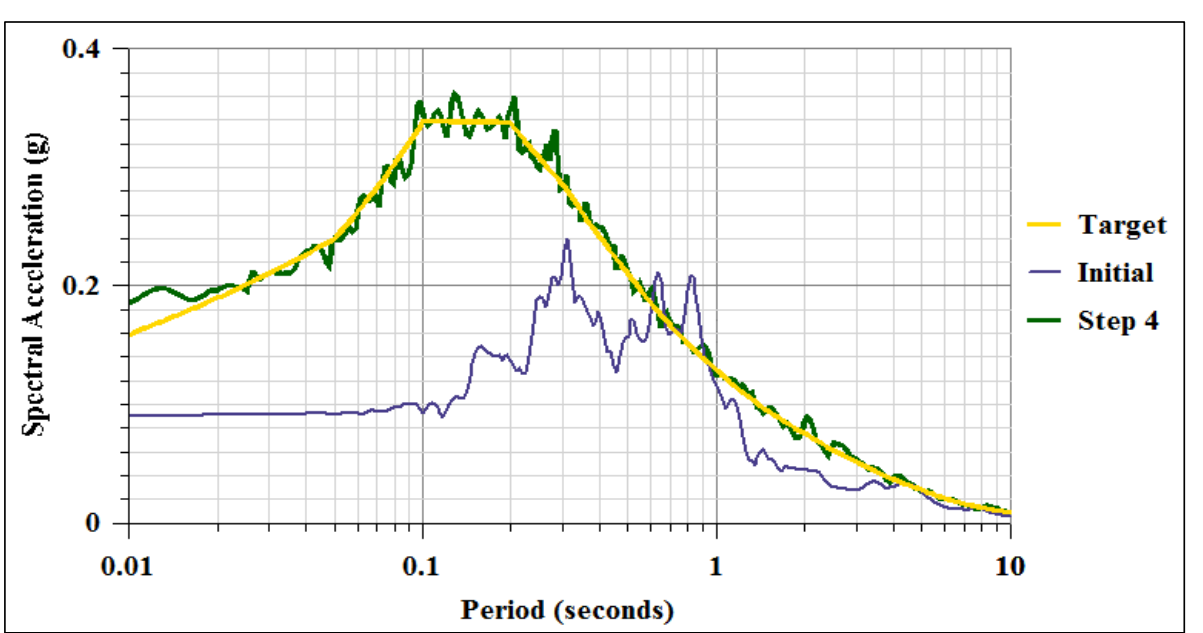

Fig. 7. Spectral matching using EZFRISK (Fugro Consultants Inc., 2014)

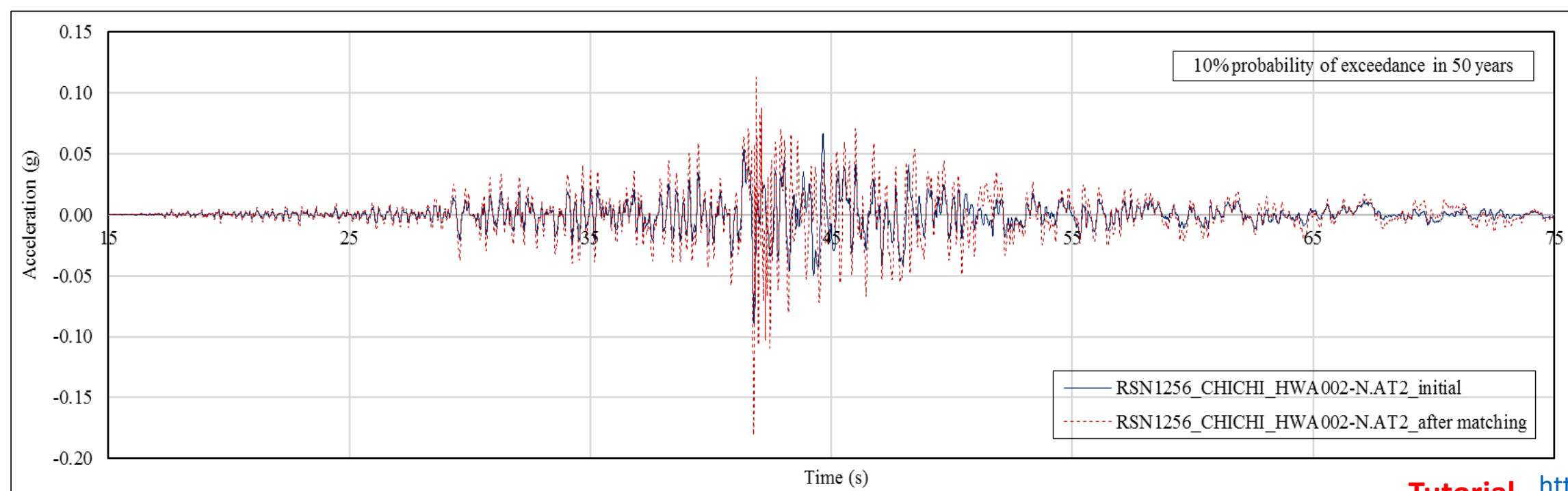

Fig. 8. Initial time history (solid blue) form the PEER NGA WEST2 database and match time history (dashed brown line) (Ancheta et al., 2013) 


\section{Nonlinear Site Response Analysis}

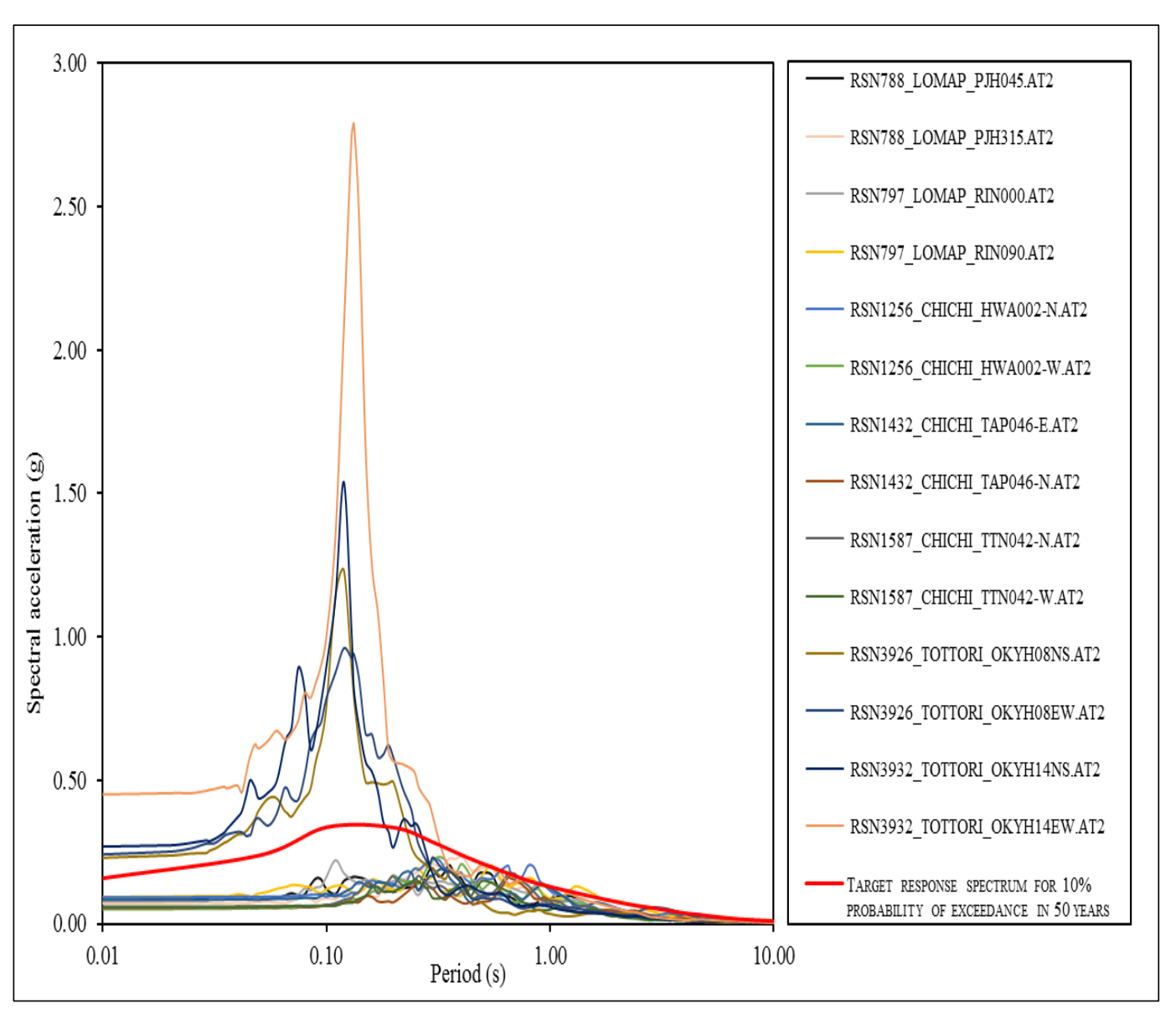

Fig. 9. Response spectra of 14 time histories from 3 earthquakes with target response spectrum for $10 \%$ probability of exceedance in 50 years at $\mathrm{BH}-03$ site

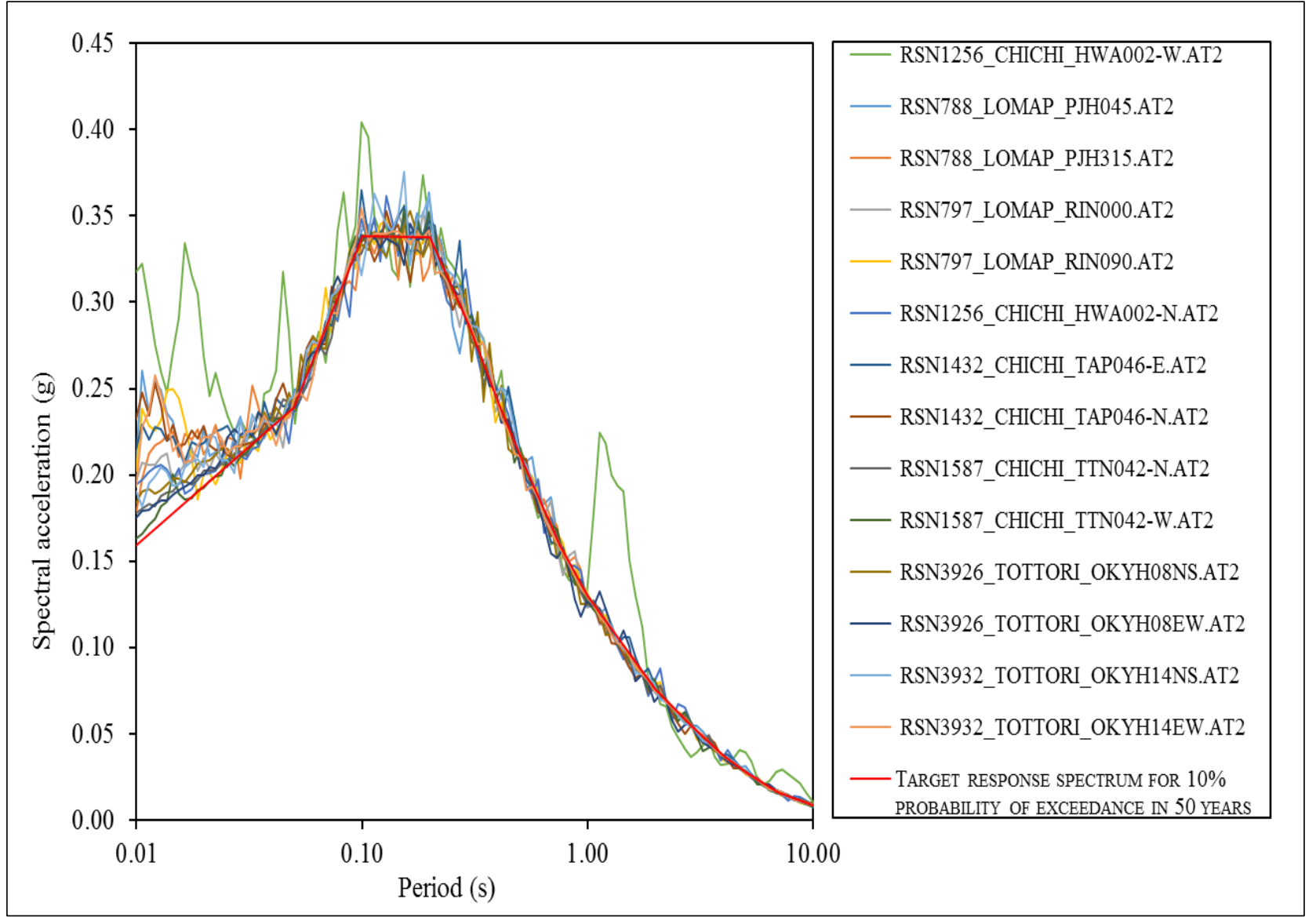

Fig. 10. Matched response spectra of 14 time histories from 3 earthquakes with target response spectrum for $10 \%$ probability of exceedance in 50 years at $\mathrm{BH}-03$ site 


\section{Nonlinear Site Response Analysis}

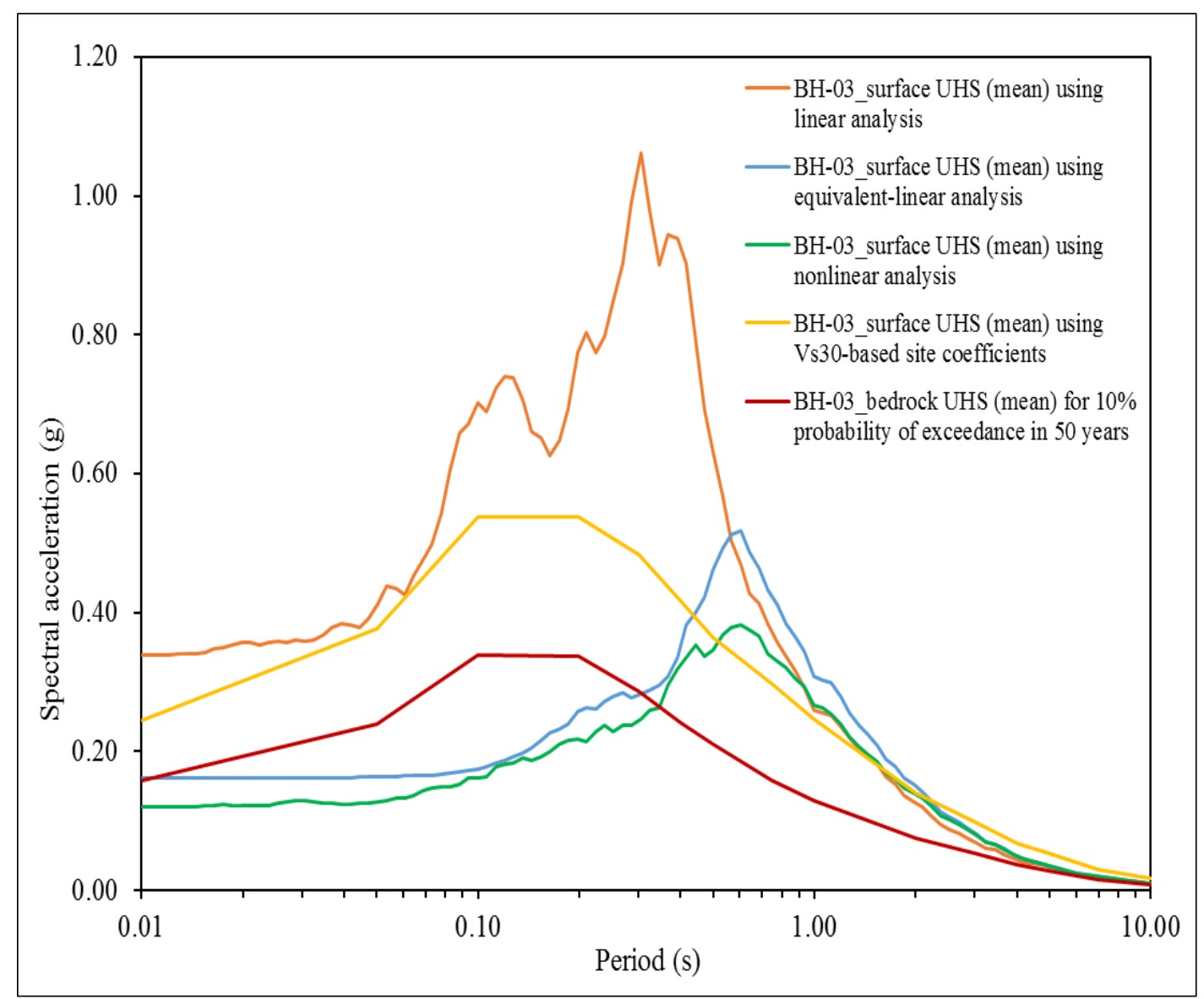

Fig. 11. Uniform hazard spectra (UHS) at ground surface using $V_{s}^{30}$-based site coefficients and UHS at ground surface using linear, equivalent-linear, and nonlinear ground response analysis at $\mathrm{BH}-03$ site using the soil profile down to a depth of $303 \mathrm{~m}$ at which the $V_{\mathrm{s}}=760 \mathrm{~m} / \mathrm{s}$.

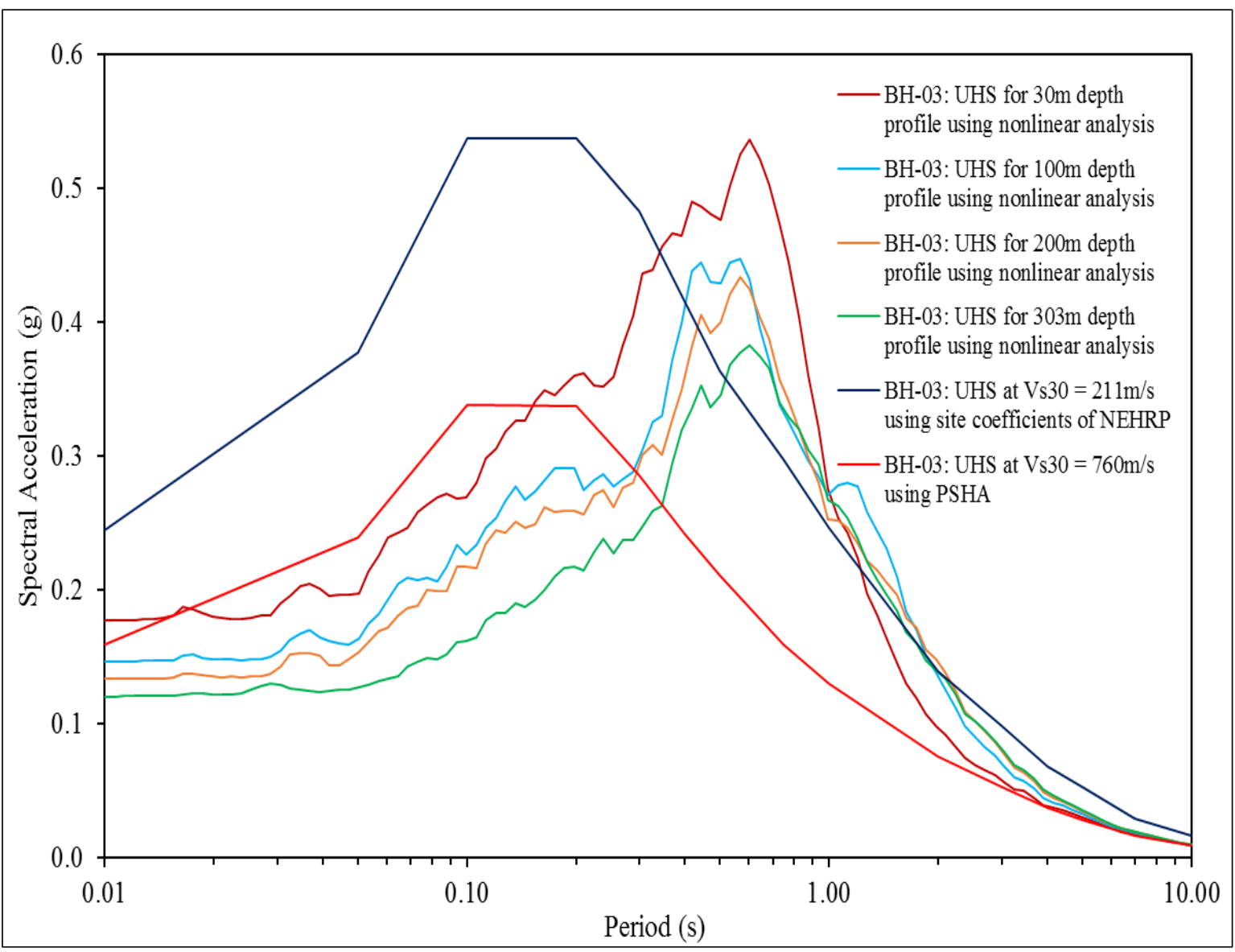

Fig. 12. Uniform hazard spectra (UHS) at bedrock condition $\left(V_{s}^{30}=\right.$ $760 \mathrm{~m} / \mathrm{s}$ ) using probabilistic seismic hazard analysis, UHS at ground surface using $V_{s}^{30}$-based site coefficients, nonlinear ground response analysis using different depths of soil profiles at $\mathrm{BH}-03$ site for $10 \%$ probability of exceedance in 50 years. 


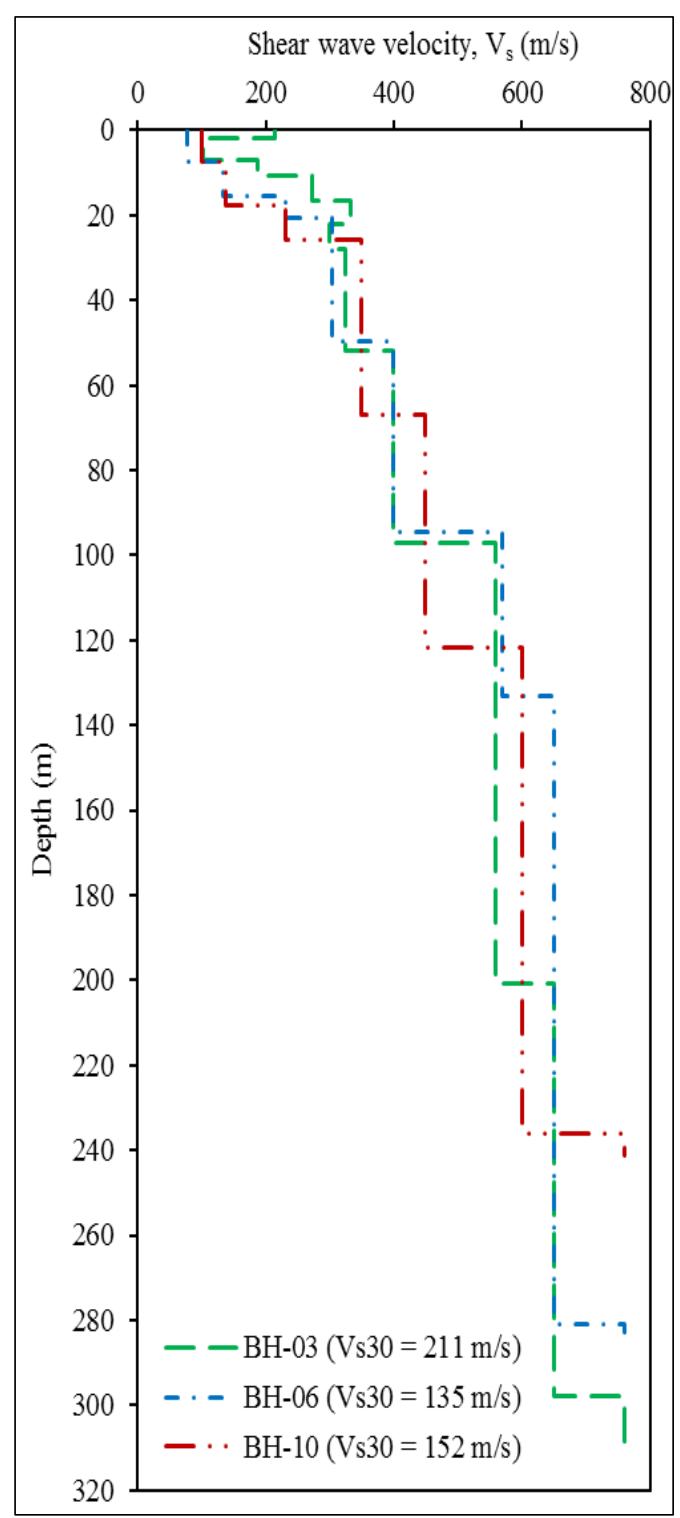

Nonlinear Site Response Analysis

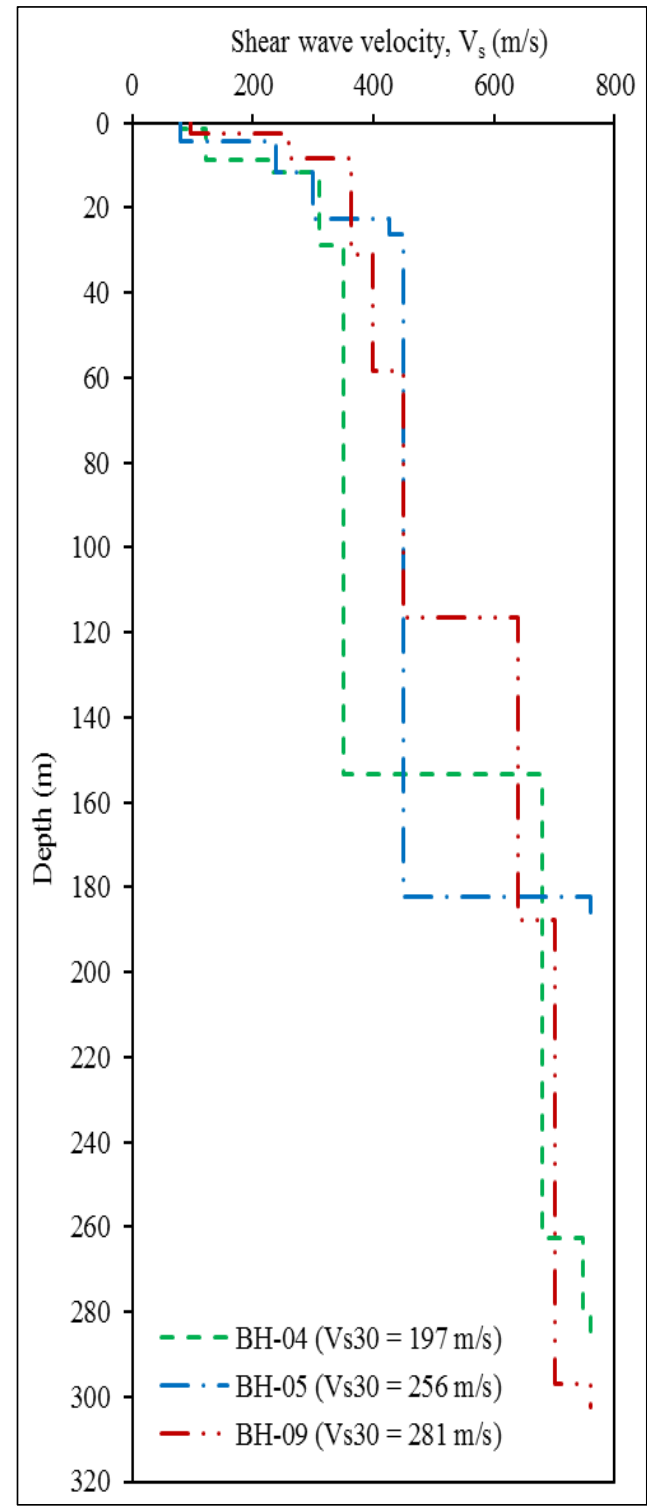

Fig. 13. shear wave velocity profile

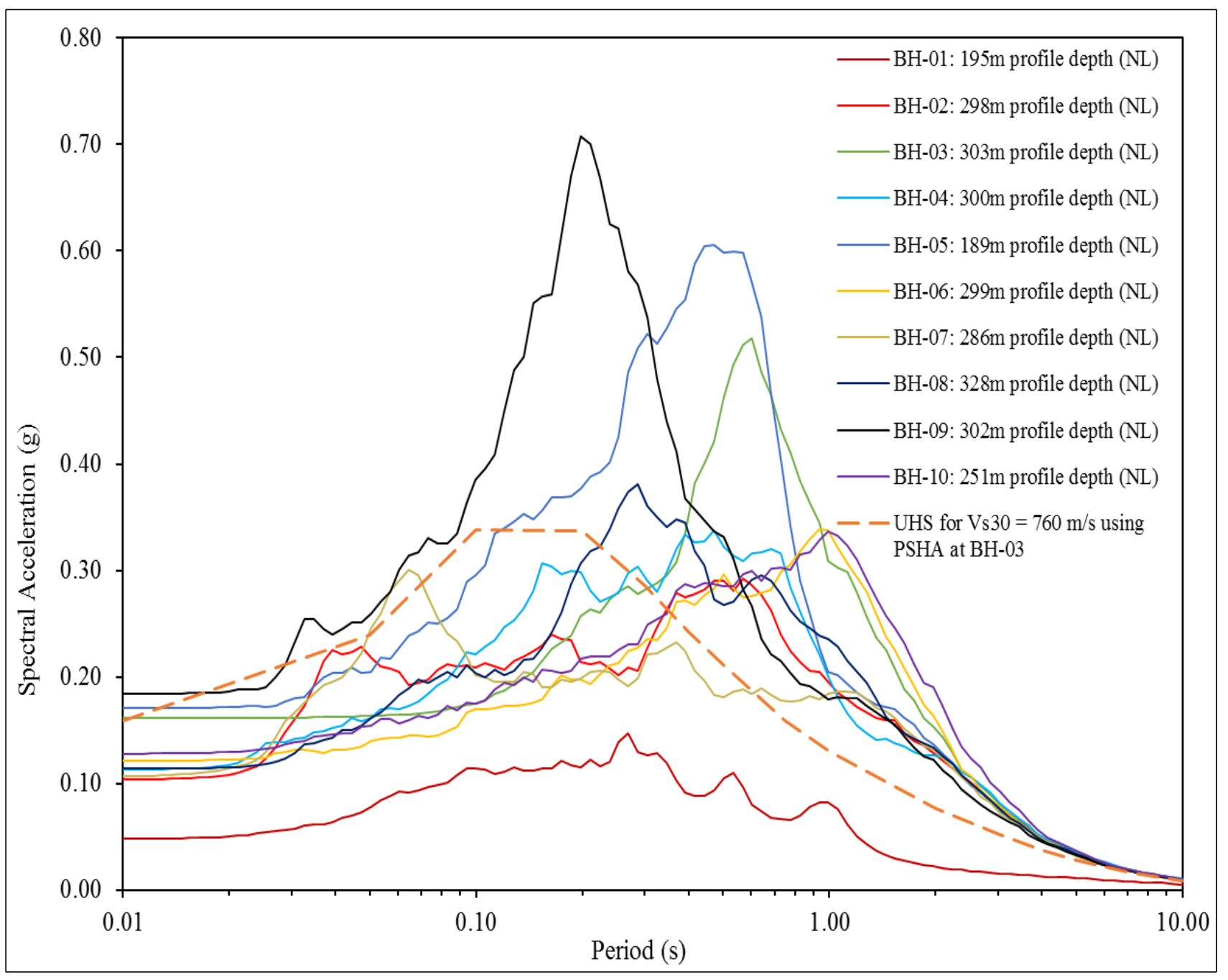

Fig. 14. Nonlinear site response at 10 sites 


\section{Nonlinear Site Response Analysis}
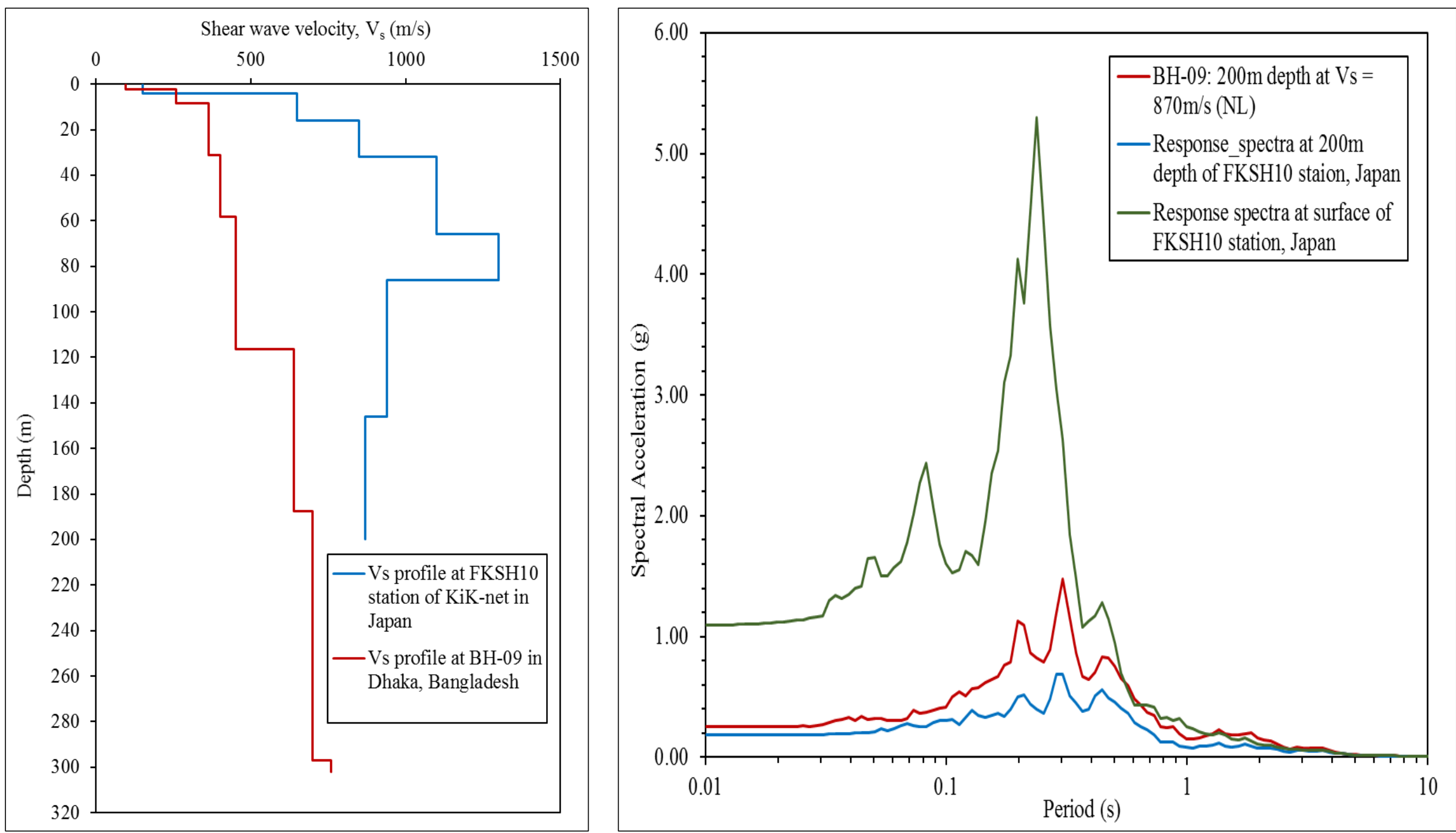

Fig. 15. Shear wave velocity profiles at BH-09 in Dhaka and at FKSH10 station of KiK-net in Japan, (b) uniform hazard spectrum (UHS) at BH-09 in Dhaka and the response spectra of the surface and borehole seismographs at FKSH10 of KiK-net station in Japan.

(Link http://www.kyoshin.bosai.go.jp/) 


\section{Conclusions}

- The bedrock motion is deamplifying at short spectral periods and amplifying at long spectral periods with the increasing depth of soft sedimentary deposits.

- The bedrock motion is always amplified in case of the $\mathrm{V}_{\mathrm{s}}{ }^{30}$-based site response analysis.

- It has been identified that large magnitude seismic sources $\left(\mathrm{M}_{\mathrm{w}}>\right.$ 8.0) are located more than $100 \mathrm{~km}$ away from the study area, therefore, the peak ground acceleration and spectral acceleration of short period seismic waves will be attenuated and spectral acceleration of long period seismic waves will be amplified in the study areas due to deep and soft deposits.

Continued... 


\section{Conclusions}

- The long period seismic waves of the far-field earthquakes will match with the natural periods of the high-rise buildings, and resonance will occur.

- The damage to high-rise buildings will be increased.

- The high-rise buildings on the deep and soft sedimentary deposits of the study area are potentially vulnerable to farfield large earthquakes.

- For deep and soft sedimentary deposits, non-linear site response analysis should be performed. 


\section{References}

1. Ancheta, T.D., Darragh, R.B., Stewart, J.P., Silva, W., Chiou, B., Wooddell, K., Graves, R., Kottke, A., Boore, D., Kishida, T., Donahue, J. (2103). PEER NGA-West2 Database.

2. BSSC (2015) NEHRP recommended seismic provisions for new buildings and other structures. Washington, D. C.

3. Fugro Consultants Inc. (2014). EZ-FRISK 7.65: Software for Earthquake Ground Motion Estimation (User's Manual), Risk Engineering, Inc. 4. Hashash, Y.M.A., Musgrove, M., Harmon, J., Ilhan, O., Groholski, D., Phillips, C., Park, D. (2017). DEEPSOIL 7.0, User Manual. 5. Kaklamanos, J., Baise, L.G., Thompson, E.M., Dorfmann, L. (2015). Comparison of 1D linear, equivalent-linear, and nonlinear site response models at six KiK-net validation sites. Soil Dyn. Earthq. Eng., 69: 207-219. 


\section{References}

6. National Research Institute for Earth Science and Disaster Resilience (2018). NIED KNET, KiK-net, National Research Institute for Earth Science and Disaster Resilience, doi:10.17598/NIED.0004.

7. Rahman MZ, Siddiqua S, Kamal ASMM (2015). Liquefaction hazard mapping by liquefaction potential index for Dhaka City, Bangladesh. Eng Geol., 188:137-147. 8. Rahman, M. Z., Siddiqua, S., Kamal, A. S. M. M. (2018). Geology and topography based $\mathrm{V}_{\mathrm{s}}{ }^{30}$ map for Sylhet City of Bangladesh. Bulletin of Engineering Geology and the Environment, 78 (5): 3069-3083.

9. Karim, M. F. and Rahman M. Z. (2002). Possible Effect of Moderate Earthquake on Existing Infrastructures of Dhaka City: A Geological-Geotechnical Overview. Bangladesh Journal of Science and Technology, Vol. 4(2), July 2002. pp 193-203. 10. Karim, M. F., Rahman, Z. M., Kamal, M., \& Siddiqua, S. (2016, 08). Site-specific earthquake hazard characterization for Dhaka City, Bangladesh. Oral and Poster Presentation at 2016 SCEC Annual Meeting. SCEC Contribution 6833, California, USA. 


\section{Acknowledgements}

- The authors would like to acknowledge:

- The University of British Columbia, Canada

- University of Dhaka, Bangladesh

- Fugro Consultants Inc., Risk Engineering, Inc., USA

- The Pacific Earthquake Engineering Research Center (PEER), USA

- National Research Institute for Earth Science and Disaster Prevention (NIED), Japan

- The developer team of DEEPSOIL, USA 


\section{Thank you all}

for your kind attention
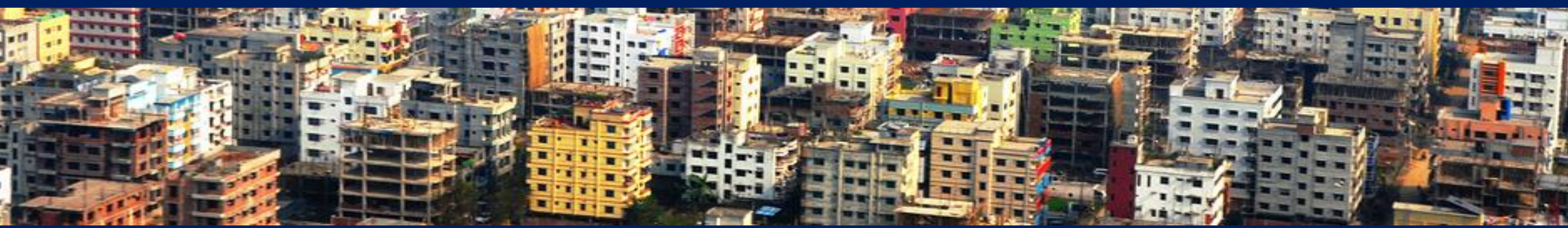

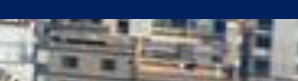

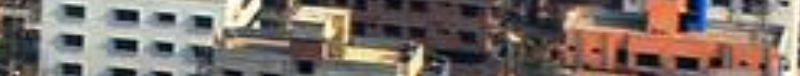

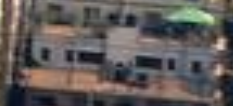
Cin $=3:=:=-1$

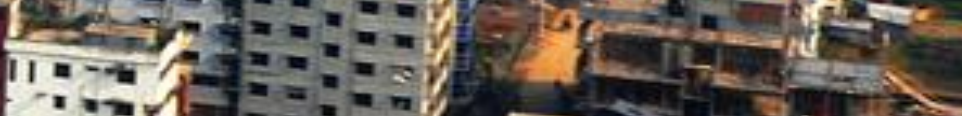
is 1 is

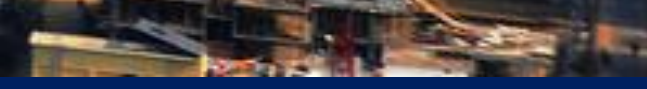

